\title{
Human-environment dynamics in European treeline ecosystems: a synthesis based on the DPSIR framework
}

\author{
A. P. Kyriazopoulos ${ }^{1}$, O. Skre ${ }^{2, *}$, S. Sarkki ${ }^{3}$, F. E. Wielgolaski ${ }^{4}$, E. M. Abraham ${ }^{5}$, \\ A. Ficko ${ }^{6}$ \\ ${ }^{1}$ Department of Forestry and Management of the Environment and Natural Resources, Democritus University of Thrace, \\ 193 Pantazidou str., 68200 Orestiada, Greece \\ ${ }^{2}$ Skre Nature and Environment, Fanaflaten 4, 5244 Fana, Norway \\ ${ }^{3}$ Cultural Anthropology, Faculty of Humanities, PO Box 1000, University of Oulu, 90014 Oulu, Finland \\ ${ }^{4}$ Department of Bioscience, University of Oslo, PO Box 1066 Blindern, 0316 Oslo, Norway \\ ${ }^{5}$ Laboratory of Range Science, Department of Forestry and Natural Environment, Aristotle University of Thessaloniki, \\ 54124 Thessaloniki, Greece \\ ${ }^{6}$ Biotechnical Faculty, Department of Forestry and Renewable Forest Resources, University of Ljubljana, Vecna pot 83, \\ 1000 Ljubljana, Slovenia
}

\begin{abstract}
The state of, and changes to, altitudinal and polar treeline ecosystems and their services in selected mountain regions in Europe were analyzed using the drivers-pressures-stateimpacts-responses (DPSIR) framework. The analysis was based on 45 responses of experts from 19 countries to 2 semi-structured questionnaires on treeline ecosystem services (ESs), stakeholders and the DPSIR factors, and 11 case study descriptions of best management practices. The experts recognized climate and land-use changes as the main drivers, resulting in various pressures that contrasted among the regions. The impacts of the pressures were mainly considered as negative (e.g. loss of biodiversity, root rot diseases, moth and bark beetle outbreaks, wild fires, decrease of (sub)alpine grasslands, browsing), but also as positive (e.g. increase in forested area). The influence of climate warming, altered precipitation regimes, a longer growing season, annual variation in winter climate and increased ground-level ozone concentrations were considered less critical for recent treeline dynamics than land abandonment, increased tourism and livestock pressure. Current policy responses to emerging pressures and stakeholder demands were considered insufficient and incoherent. Mitigation, adaptation and restoration actions were rare and with no evident long-term impact. We conclude that (1) locally-specific human-environment interactions have greater influence on treeline dynamics than global warming; (2) ecological and social sustainability of the treeline areas can be enhanced by simultaneously promoting traditional land use and regulating tourism development; (3) ES users should look for new opportunities arising from environmental change rather than trying to sustain current levels of ESs indefinitely; and (4) to safeguard the unique ecological and social values of treeline areas, more coherent and proactive policies are needed.
\end{abstract}

KEY WORDS: Mountain forests - DPSIR framework - Climate change $\cdot$ Land-use change · Ecosystem services $\cdot$ Disturbances $\cdot$ Biodiversity

\section{INTRODUCTION}

Mountain forest ecosystems are among the most endangered ecosystems in the world (Broll \& Keplin

${ }^{*}$ Corresponding author: oddvar@nmvskre.no

${ }^{\S}$ Advance View was available online May 18, 2017
2005). In Europe and elsewhere, climate change (Theurillat \& Guisan 2001, Grace et al. 2002, Skre et al. 2002, Kullman \& Öberg 2009, Smith et al. 2009), and land-use change (Bryn \& Daugstad 2001,

() The authors 2017. Open Access under Creative Commons by Attribution Licence. Use, distribution and reproduction are unrestricted. Authors and original publication must be credited. 
Gehrig-Fasel et al. 2007, Hofgaard et al. 2013, Ameztegui et al. 2016) are 2 important drivers of environmental change. The treeline ecotone (Holtmeier 2009) can be particularly useful as an early indicator of environmental change (Kupfer \& Cairns 1996). Altitudinal and polar treeline ecotones are primarily controlled by climate, as seasonal mean temperature decreases with increasing elevation and latitude. The isotherm theory for natural treeline formation has been confirmed in several empirical studies and modelling exercises (Paulsen \& Körner 2014). However, centuries of human disturbances have altered the climatic position of treelines. To capture the complexity of factors influencing the dynamics of treeline ecotones, the ecological definition of a treeline as an ecotone should be extended to include 'treelinerelated administrative areas, and associated landscapes and ecosystems' (Sarkki et al. 2016a, p. 2020).

The contributions that ecosystems make to human well-being arising from the interaction of biotic and abiotic processes (Grunewald \& Bastian 2015) have been described as ecosystem services (ESs). To systematically arrange the benefits that humans receive from nature, several ES classifications have been proposed (e.g. Boyd \& Banzhaf 2007, Luck et al. 2009) and used in studying the treelines (e.g. Sarkki et al. 2016a), such as classification into provisioning, regulation and maintenance, and cultural services.

The subalpine and subarctic forests close to the treeline provide a number of resources for local communities with traditionally low land-use intensity. They provide regulating ESs, such as erosion and flood control and reduction of environmental risks such as avalanches and forest fires. Access to exclusive and non-exclusive ESs may potentially cause conflicts among stakeholders due to overuse of some ESs by some stakeholders. Treeline ESs have been analyzed in small areas at or near the treeline and for certain ESs in mountainous regions (e.g. Grabherr 2009, Hastik et al. 2015). However, there is little information regarding Europe-wide mapping of ESs combined with stakeholder and governance analysis. Sarkki et al. (2016a), for instance, identified key ESs in European treeline areas, along with treeline-relevant stakeholders and the threats they pose to, and benefits they receive from, ESs. They found contextand treeline-specific behavior of stakeholders and governance structures that insufficiently addressed the sustainability of these areas. A similar finding was obtained by Sarvašová et al. (2014). However, to be able to understand the pressures on treeline ESs and adaptive responses, a holistic framework is required for studying cause-effect relationships in treeline areas (see Sarkki et al. 2017a, this Special).

In this context, the drivers-pressures-state-impactsresponses (DPSIR) framework (see Section 2.1 below) is useful for describing the interactions between society and the environment. It has been adopted by the European Environment Agency (EEA 2016) to show how social-ecological systems function in a dynamic way and what the interactions are among different factors. The 'drivers' (e.g. climate and land-use change) create 'pressures' that are causing social-ecological changes in treeline areas. The resulting change in the 'state' of the social-ecological system has 'impacts' on the functioning of the system, but societal 'responses' may restore the desired state or reduce pressure, trying to make the social-ecological system resilient to change (cf. Fig. A1 in the Appendix)

This study examines factors influencing humanenvironment dynamics at or near European treelines by synthesizing various results of the SENSFOR project ('Enhancing the resilience capacity of SENSitive mountain FORest ecosystems under environmental change'). Empirical results summarized in this paper have been previously published as technical reports, but with no overall synthesis. In this study, pressures to treeline ESs (Kyriazopoulos et al. 2014), the state of ESs in treeline areas (Sarkki et al. 2013) and potential policy responses (Sarkki et al. 2015, 2016a,b, 2017b, this Special) are synthesized under the DPSIR framework for the first time. We summarize the most important DPSIR factors and their threats to, and benefits for, the coupled human-environmental system and ESs. This synthesis allows us to draw conclusions about the relationships between ecological and social sustainability in European treeline areas and their relationships to governance responses.

\section{METHODOLOGY}

\subsection{The DPSIR framework}

The DPSIR framework is a well-established causal framework for describing the interplay between the environment and socio-economic activities (EEA 2016) that has its roots in the stress-response environmental statistical system (S-RESS) proposed by Friend (1979). The basic logic behind the DPSIR framework is that any status or change in a social-ecological system is related to its driving forces and pressures through a number of feedbacks. Humans play a determinant role in steering the social-ecological system and structuring its state. 
The DPSIR framework belongs to the family of systems analysis frameworks. It shares many similarities with the Framework for the Development of Environment Statistics (FDES), the Pressure-State-Response (PSR) framework, the Pressure-State-Response/Effect (PSR/E) framework, the Pressure-State-Impact-Responses (PSIR) framework and the Driver-PressureState-Welfare-Response (DPSWR) framework (see Cooper 2013 for a review).

Applications of the DPSIR framework in practice differ with regard to the interpretation of DPSIR factors, and may include a number of modifications. We used an interpretation that closely follows the original definition by the EEA (2016). For each of the categories in the DPSIR framework, we present the most important factors and issues as reported by the respondents and discuss how these categories link to each other. Responses were grouped into restoration practices, adaptation practices and mitigation measures.

\subsection{Surveys}

To identify the DPSIR factors, we used the multiple case study analysis, which is a qualitative technique of data gathering when representative sampling is difficult to conduct. The multiple case study analysis enabled us to generalize causalities between the drivers, pressures, state, impact and responses based on similarities in patterns and processes.

We sent 2 questionnaires and a call for detailed case study descriptions to more than 100 experts from 20 European countries to obtain the widest possible assessment on the state of altitudinal and polar treelines in Europe. The aims of these surveys were to (1) analyze the present state of, and potential changes in, ecosystems with a particular focus on identifying DPSIR factors in each case study region; (2) map the drivers and pressures of ecosystem change; (3) analyze the history and present state of ecosystems and their services for different land uses and management practices, including the identification of trends in ES delivery capacity and socio-political adaptation; (4) identify current societal responses to ES-related challenges; and (5) generate a holistic understanding of treeline ecotone ecosystems and their services, based on the DPSIR framework.

The first questionnaire consisted of mainly closedended questions on the relevance of ESs, stakeholder benefits from, and threats to, ESs, and governance and science-society relationships. The questionnaire was sent in 2013 to approximately 100 SENSFOR con- sortium members (Sarkki et al. 2013, 2016a, Table 1). The assessment of ESs was based on the Common International Classification of Ecosystem Services using 5-point Likert scale (Sarkki et al. 2016a). Altogether, 22 treeline case study descriptions from 15 countries were received, describing 20 different treeline areas in Europe (see Sarkki et al. 2013, 2016a for detailed description of the methodology and the questionnaire). Stakeholder benefits from, and threats to, treeline ESs were then cross-tabulated with pressures identified in the second questionnaire.

The second questionnaire was distributed to more than 100 experts in late 2013 using the SENSFOR and Mountain Research Initiative (MRI) network. This mostly open-ended questionnaire (see Kyriazopoulos et al. 2014 for the questions) used the DPSIR framework, and also included a request for a detailed description of the size, altitude, latitude, climate, geology, dominant tree species and the major wild, semi-domestic and domestic herbivores in the area. The questionnaire included several questions regarding land-use change and climate change trends to estimate possible effects of these 2 drivers (see Table A1 in the Appendix). A total of 26 responses from different European treeline case study regions were received. A follow-up questionnaire was distributed in mid-2014 to all who responded to this questionnaire, focusing on the state and responses in the treeline areas. Eight responses from different treeline areas were received in the second round (Kyriazopoulos et al. 2014).

A call for detailed case study descriptions was sent in 2015 to SENSFOR consortium members asking them to describe best management practices in European treeline areas and to suggest proposals for enhanced governance of treeline areas. Eleven descriptions of successful and failed practices were received, identifying 75 proposals for enhanced governance. These proposals were inductively clustered into several groups (Sarkki et al. 2015, 2017b).

\section{RESULTS AND DISCUSSION}

\subsection{Drivers}

Climate change and land-use change were recognized as the main drivers of treeline ecotone dynamics (cf. Kyriazopoulos et al. 2014). Although highresolution spatio-temporal data indicating directional impact of climate or land-use change were not provided, both drivers were unanimously suggested as being of major importance for all case study regions. 
Table 1. Case study areas used for the assessment of human-environment dynamics in European treeline areas (adapted from Kyriazopoulos et al. 2014, Sarkki et al. 2015, 2016a, 2017b). ES: ecosystem services; DPSIR: drivers-pressures-state-impactsresponses framework, NP: National Park

\begin{tabular}{|c|c|c|c|c|c|}
\hline \multirow[t]{2}{*}{ Country } & \multirow[t]{2}{*}{ Case study area } & \multirow[t]{2}{*}{ Type } & \multicolumn{3}{|c|}{ Questionnaire on: } \\
\hline & & & $\begin{array}{l}\text { ES, stakeholders } \\
\text { and governance }\end{array}$ & $\begin{array}{l}\text { The } \\
\text { DPSIR }\end{array}$ & $\begin{array}{l}\text { Good environmental } \\
\text { management }\end{array}$ \\
\hline Iceland & Almenningar, Southern Iceland & Polar & $\checkmark$ & $\checkmark$ & \\
\hline Ireland & Burrishoole & Non-climatic & $\checkmark$ & & \\
\hline Spain & Cantabrian range, Iberian peninsula & Altitudinal & & $\checkmark$ & \\
\hline Slovakia & Carpathian Mts. & Altitudinal & & $\checkmark$ & \\
\hline Russia & Caucasus Mts. & Altitudinal & & $\checkmark$ & \\
\hline Italy & Central Alps & Altitudinal & & $\checkmark$ & \\
\hline Spain & Central Pyrenees & Altitudinal & $\checkmark$ & & $\checkmark$ \\
\hline Slovenia & Dinaric Mts, Sneznik Mt. & Altitudinal & $\checkmark$ & & \\
\hline Serbia & Dinaric Mts., Tara NP & Altitudinal & & $\checkmark$ & \\
\hline Norway & Dovre Mt., Central Norway & Altitudinal & & $\checkmark$ & \\
\hline Czech Republic & Hercynian Mts. & Altitudinal & & $\checkmark$ & \\
\hline Ukraine & $\begin{array}{l}\text { Khust and Rachiv regions, villages } \\
\text { Nyzhniy Bystry and Bohdan, } \\
\text { Carpathians }\end{array}$ & Altitudinal & & & $\checkmark$ \\
\hline Russia & Khybini Mts., Kola Peninsula & Polar & & $\checkmark$ & \\
\hline Finland & $\begin{array}{l}\text { Kilpisjärvi-Käsivarsi region, } \\
\text { NW Finnish Lapland }\end{array}$ & Altitudinal & $\checkmark$ & & $\checkmark$ \\
\hline Sweden & Lake Torneträsk Catchment (Abisko) & Altitudinal & $\checkmark$ & & \\
\hline UK & $\begin{array}{l}\text { Lochaber Forest District, } \\
\text { North Western Scotland }\end{array}$ & Non-climatic & & & $\checkmark$ \\
\hline Ukraine & $\begin{array}{l}\text { Lviv, Chernivtsi and Ivano-Frankivsk } \\
\text { regions, Carpathians }\end{array}$ & Altitudinal & & & $\checkmark$ \\
\hline Italy & Majella NP, central Apennines & Altitudinal & $\checkmark$ & $\checkmark$ & \\
\hline Spain & Montseny, NE Spain & Altitudinal & & $\checkmark$ & \\
\hline UK & $\begin{array}{l}\text { Moray, Aberdeenshire and the } \\
\text { Dee river catchment, Cairngorms NP }\end{array}$ & Non-climatic & $\checkmark$ & $\checkmark$ & $\checkmark$ \\
\hline Greece & Mount Parnon, South Greece & Altitudinal & & $\checkmark$ & \\
\hline Finland & Muonio, North western Lapland & Altitudinal & & & $\checkmark$ \\
\hline Finland / Norway & Northern Fennoscandia & Polar & & $\checkmark$ & \\
\hline Norway & Northern Norway & Polar & & $\checkmark$ & \\
\hline Spain & Northern Pyrenees & Altitudinal & & $\checkmark$ & \\
\hline Sweden / Norway & Northern Scandinavia & Polar & $\checkmark$ & & \\
\hline Germany & Berchtesgaden-Alps NP & Altitudinal & $\checkmark$ & & \\
\hline Bulgaria & Central Balkan NP & Altitudinal & $\checkmark$ & & \\
\hline Romania & Piatra Craiului NP & Altitudinal & $\checkmark$ & & \\
\hline Italy & $\begin{array}{l}\text { Paneveggio-Pale di San Martino NP, } \\
\text { Eastern Alps }\end{array}$ & Altitudinal & $\checkmark$ & $\checkmark$ & \\
\hline Portugal & Peneda do Geres NP & Altitudinal & & $\checkmark$ & $\checkmark$ \\
\hline Greece & Pindos Mts. & Altitudinal & $\checkmark$ & $\checkmark$ & $\checkmark$ \\
\hline Greece & Psiloritis, Crete & Altitudinal & & $\checkmark$ & \\
\hline Bulgaria & Rila and Pirin Mts. & Altitudinal & $\checkmark$ & $\checkmark$ & $\checkmark$ \\
\hline Spain & Sierra Nevada & Altitudinal & & $\checkmark$ & \\
\hline Slovenia & South-Eastern Alps & Altitudinal & & $\checkmark$ & \\
\hline Norway & Southern Norway (Hardangervidda) & Altitudinal & $\checkmark$ & & \\
\hline Spain & Southern Pyrenees & Altitudinal & & $\checkmark$ & \\
\hline Bulgaria & Stara Planina & Altitudinal & & $\checkmark$ & \\
\hline Czech Republic & Sudeten Mts. & Altitudinal & $\checkmark$ & & \\
\hline Slovakia & Tatra NP, Dolina Parichvost & Altitudinal & & & $\checkmark$ \\
\hline Slovakia & West Carpathians & Altitudinal & $\checkmark$ & $\checkmark$ & \\
\hline Slovakia & Západné Tatry Mts. (Western Tatras) & Altitudinal & $\checkmark$ & & \\
\hline
\end{tabular}



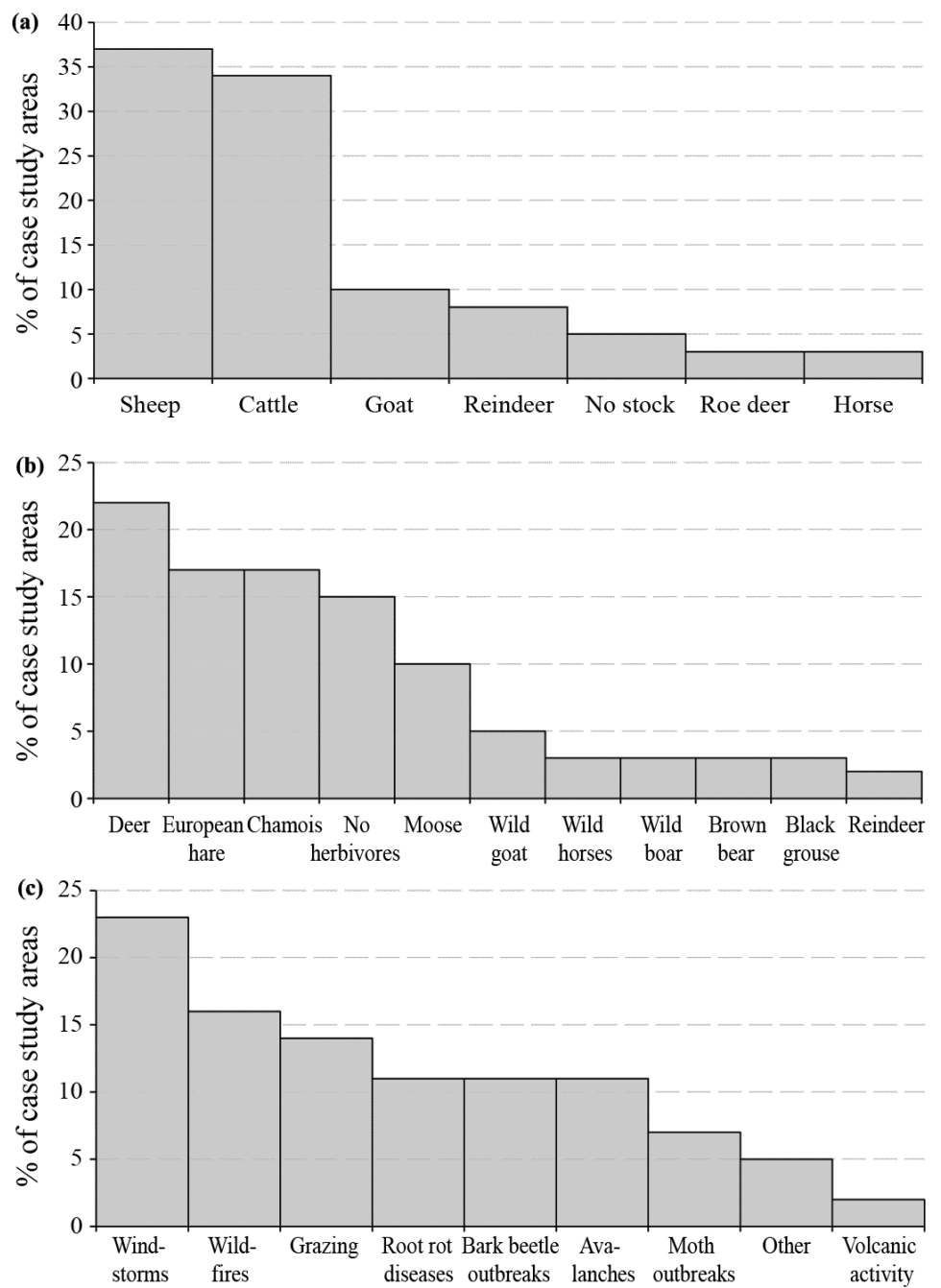

Fig. 1. (a) Main grazing stock, (b) wild herbivores and (c) main disturbances at and near treeline ecotones in Europe (based on Kyriazopoulos et al. 2014)

It is well-documented that treeline ecotones are sensitive to climatic fluctuations and, consequently, are useful indicators of climate change (Theurillat \& Guisan 2001, Grace et al. 2002, Smith et al. 2009, Kullman \& Öberg 2009). However, Kupfer \& Cairns (1996), among others, warned against the limitations of using treelines as climate change indicators in highly altered anthropogenic landscapes. Firstly, the response of an ecotone to changing climate is at a timescale of several decades, in which these impacts may be difficult to disentangle from impacts of more short-term duration. Moreover, although tree growth in general becomes more and more constrained by the harsher environmental conditions associated with increasing altitude or latitude (Körner 2012), the altitudinal or latitudinal forest- and tree-limits may show different responses to climate change (Hofgaard et al. 2013), mostly due to differences in upslope edaphic limitations and competitive interactions with established canopy and subcanopy individuals (Kupfer \& Cairns 1996).

The main changes that can counteract climate-driven forest expansion, especially at the local level (Debussche et al. 1999), are land-use changes. Land-use changes in treeline areas have been strongly linked to the dynamics of the socio-economic systems in Europe over the last century (e.g. reduced summer farming in Scandinavia; Bryn \& Daugstad 2001). Locally-specific impacts of land-use changes are described in detail in Section 3.2. In Iceland, volcanic activity was identified as a driver causing specific natural disturbances. Other disturbances, such as insect attacks, wildfires and windthrows were classified as pressures related mostly to climate change.

\subsection{Pressures}

The pressures acting on the treeline ecotones were divided into 3 categories according to the forces driving them: (1) climate change, (2) land-use changes and (3) volcanic activity. Our findings suggest that in the past decades, land-use changes have been more critical for treeline dynamics than climate change.

According to the respondents, the main pressure related to climate change was climate warming, which was sometimes accompanied with increased precipitation, resulting in a longer growing season, summer drought, and inter-annual variation in winter climate as well as increased ground-level ozone concentrations (cf. Kyriazopoulos et al. 2014). A longer growing season was reported as a positive result of the warmer climate in most of the northern and the central European study areas. The predicted warmer climate could potentially move the treeline ecotone toward more northern latitudes. Kullman (2004) reported that seedlings of white birch Betula pubescens, Norway spruce Picea abies and Scots pine Pinus sylvestris have recently become established 500-700 $\mathrm{m}$ above their recent tree limits. However, occurrence of tree seedlings above the tree limit may also be interpreted as part of the natural dynamics of the zone, 
with largely ephemeral seedling populations (Hofgaard et al. 2013). An advance of the treeline ecotone will probably cause an increase in forest cover and create the potential for development of local forestrydependent economies, but this process could take decades or centuries (Skre et al. 2002, Van Bogaert et al. 2011, De Wit et al. 2014). In contrast, inter-annual variation in winter climate and summer drought was reported as a negative result of climate change, particularly in the southern European regions (cf. Kyriazopoulos et al. 2014).

Land abandonment was identified as the major pressure arising from land-use change. This pressure manifests through abandonment of traditional pastoral activities mirroring the socio-economic changes in mountainous areas. The most common pressure was abandonment of pastures due to a decrease in livestock (54\% of cases). The impact of this change was considered positive in all cases except in the southern part of the Balkan Peninsula and some parts of the Carpathian Mountains. Some respondents reported land abandonment in general (13\%) and an increase in grazing $(11 \%)$, the latter reported only from northern Europe and in Crete, Greece. Increased livestock farming was related to an increasing demand for high-quality reindeer and goat products, and local livestock farming traditions (Kyriazopoulos et al. 2014). Our results confirmed the conclusions of several studies, that the current treeline position mostly occurs well below its potential location due to the long history of anthropogenic disturbances such as clear-cutting, burning and grazing (e.g. Gehrig-Fasel et al. 2007, Palombo et al. 2013, Ameztegui et al. 2016).

Populations of grazing livestock were found to be decreasing in $67 \%$ of the study regions, increasing in $12 \%$ and stable in $17 \%$; there was no data for the rest of the cases. The most important grazing stocks in European treeline areas (Fig. 1) include cattle and sheep (34 and $37 \%$, respectively), goats $(10 \%)$ and semi-domestic reindeer $(8 \%)$. Horses and roe deer were considered less important pressures ( $3 \%$ each).

Livestock grazing was recognized as a positive pressure, since high grazing intensity reduces or prevents tree establishment (Potthoff 2009). In some cases in Spain and Greece, the abandonment of grazing in treeline ecosystems was recognized as unfavorable due to shrub encroachment, which could pose a serious threat to forage productivity and biodiversity of the subalpine grasslands. In these regions, grazing was recognized as an ecological tool to restore or conserve these habitats (Papanastasis 2009). Using similar justification, some respondents described increased livestock grazing as negative because of disturbances to vegetation dynamics and an increase in soil erosion. However, a negative effect of livestock grazing was highlighted in only a few case study areas in northern Europe and Crete, Greece.

Wild herbivores were described as a pressure in $90 \%$ of the case studies (Fig. 1b); Cervidae (deer family), European hare Lepus europaeus and chamois Rupicapra spp. were among the main species in 22,17 and $17 \%$ of the case studies, respectively. Additionally, elk Alces alces was listed as a pressure in $10 \%$ of the cases, but in certain areas (e.g. Scandinavia) it occurs along with wild reindeer Rangifer tarandus. Wild goat Capra aegagrus, brown bear Ursus arctos, wild boar Sus scrofa and black grouse Tetrao tetrix were reported at lower percentages (3-5\% of the cases).

For some areas in Europe, i.e. Scotland and northern Fennoscandia (Danell et al. 1991, Oksanen et al. 1995, Hester et al. 2004) the impact of wild and semi-domestic herbivorous species on treeline vegetation is well-documented. In addition to the negative effect of grazing on treeline vegetation, large ungulates may also contribute to local livelihood through income obtained from hunting and tourism (e.g. Hester et al. 1996, Tolvanen et al. 2005, Sarkki et al. 2013). Furthermore, environmental policies may multiply pressures on treeline ES and stakeholders by applying strict conservation guidelines for predators (U. arctos, grey wolf Canis lupus, Eurasian lynx Lynx lynx, eagles) and support for tourism development.

Intensive tourist activity was considered as a negative pressure in $19 \%$ of the cases. Although increased numbers of tourists may financially benefit local communities, it can also negatively impact sensitive ecosystems and species, mainly due to the construction of infrastructure. Furthermore, in some cases industrial development (including mining, and the construction of hydropower plants and windmills) was recognized as a pressure. A majority of the respondents identified limited or no logging activities in the treeline ecotones. The only exception was reported from Caucasus, and was considered a negative effect. Pressures related to volcanic activity were identified only in Iceland. They were reported as negative, as lava and ash can destroy the treeline vegetation.

\subsection{State}

The state of treeline ecosystems varies greatly by country and region. Here, we describe exemplary states of treelines in 8 case studies (Kyriazopoulos et 
Scientists

Protected area officials

Tourism

State parks

Recreationists

Hikers

EU

Schools

Rural tourism

Bird watchers

NGOs

Residents as water users

State forestry institutions

Wildlife watchers

Tour operators

Ski resorts

Permanent residents

Landowners

Hunters

Pastoralists

Downhill skiers

Second home owners

Nonwood product gatherers

Crosscountry skiers

Fishermen

Agriculture irrigators

Private forest companies

Snowmobile users

Forest owners

Hydropower companies

Army

Conventional farmers

Small-scale farmers

Windpower companies

Mining companies

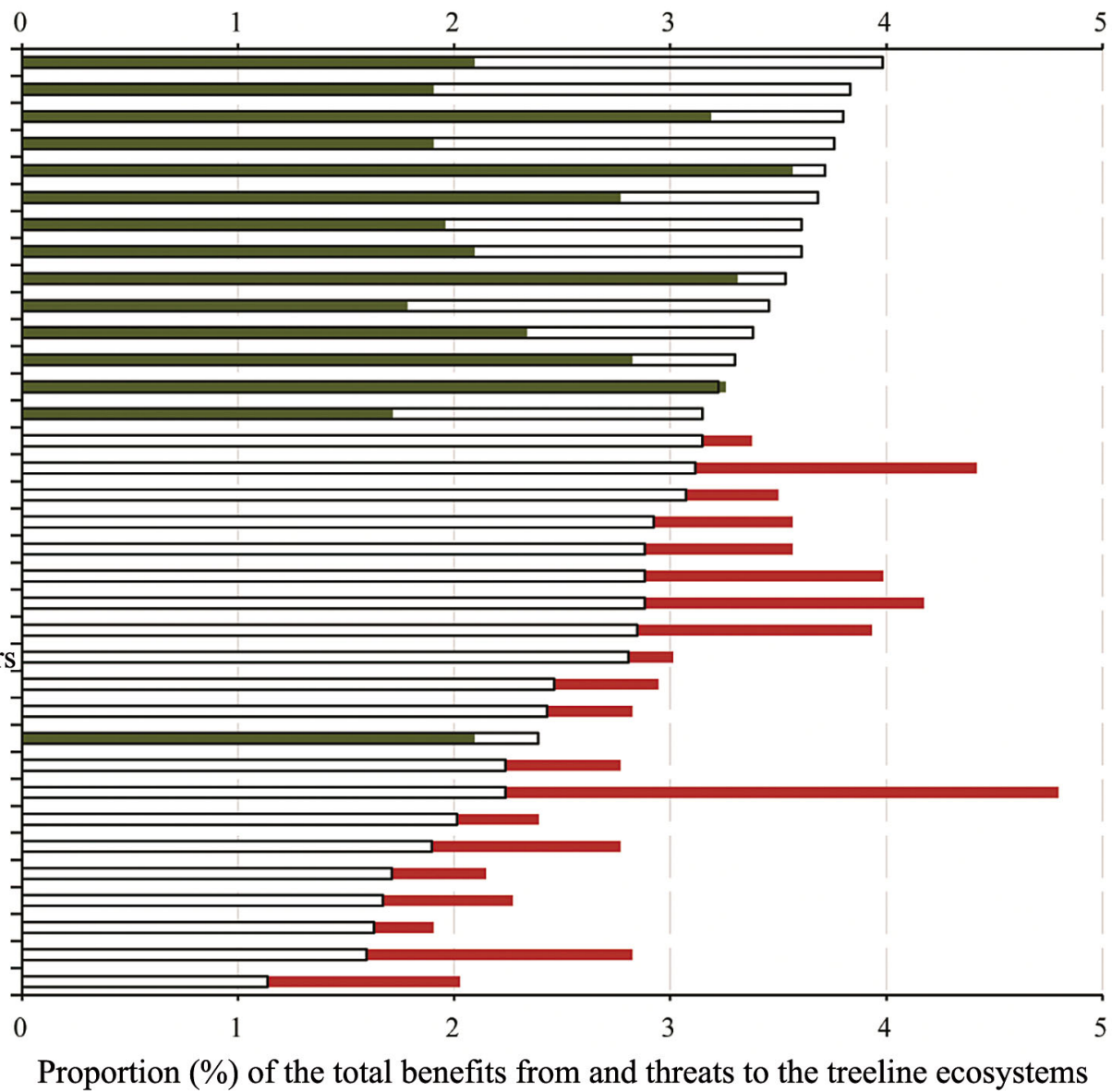

Fig. 2. Main stakeholders in European treeline areas sorted top-down on a scale from 0 to 5 by the benefits they obtain from treeline ecosystems (white bars: the degree a stakeholder gets of the total benefits produced by treeline ecosystems). Colored bars (green or red): degree of the total threats to the treeline ecosystems that is attributable to a certain stakeholder. If this percentage is lower than the percentage the stakeholder gets of the total benefits produced by treeline ecosystems, the bar is colored green (net receivers), else red (net-givers). 'Ski resort business', 'Downhill skiers' and 'Tour operators' are different forms of the tourism industry. 'Recreationists', 'Hikers', 'Bird watchers' and 'Crosscountry skiers' are different forms of nature-based tourism

al. 2014) to illustrate the diversity of the pressures in different parts of Europe.

Most of the Pyrenean treeline ecotones (Spain) were severely disturbed by humans in the past (e.g. grazing and logging), but in the period from the 1930s until 1980, sheep densities decreased in concert with a $61 \%$ decrease in the human population (Alados et al. 2014). As a result, $24 \%$ of the subalpine grasslands under $2100 \mathrm{~m}$ a.s.l. in the Central Pyrenees reverted to forest between the 1980s and 2000s (Gartzia et al. 2014). Since 1960, industrial development, the intensification of agriculture and development of the skiing industry have been the prevailing human activities. Several areas show destruction of the vegetation due to overgrazing and extreme erosion, which is usually conditioned by local topography and disturbances such as snow avalanches (Cudlín et al. 2017, this Special). Elsewhere, encroaching scrublands (horrible broom Echinospar- tum horridum, snow rose Rhododendron ferrugineum) dominate former grassland above the current treeline (Camarero et al. 2015). The expansion of woody plants has affected biodiversity and the goods and services provided by grasslands. It has also altered the spatial distribution of wild animals. $S$. scrofa, for instance, is now found to be feeding on grasslands, which rarely happened before.

In the Central Stara Planina Mountains (Bulgaria), burning and grazing in areas near the treeline has resulted in the replacement of conifers by European beech Fagus sylvatica and reduced soil carbon storage capacity (Grunewald \& Scheithauer 2011). Forest conversion has also decreased soil organic matter. However, climate warming is expected to contribute to upslope advance of conifers as well as F. sylvatica (Dakov et al. 1980). Land-use intensity also influenced the quality and composition of soil humus in mountain grasslands. The alteration of natural vege- 
tation was mostly due to fire and grazing (Cudlín et al. 2017). Today, only few cattle graze on Bulgarian highaltitude pastures. In the last few decades, changes to the timberline have mainly been caused by winter sport facilities (Grunewald \& Scheithauer 2011).

The current state of Pindos Mountain treeline ecotones (northern Greece) indicates intense human activities in the past, which have since been strongly reduced. As a result, soil erosion risk is being minimized. As a result of land abandonment, shrub encroachment by junipers Juniperus spp. in formerly grazed grasslands is common. Further decreases in livestock grazing may negatively affect both floristic and faunistic diversity, especially populations of raptors (Bakaloudis 2016). Conversely, in Psiloritis (Crete), decades of overgrazing have contributed to severe soil erosion. Desertification has become a serious problem, particularly due to fires set by the shepherds to combat unpalatable species, followed by continuous, heavy grazing. However, pastoral activities have positively influenced biodiversity. There is still a relatively high population of raptors in Crete (Xirouchakis 2004). Reduced tree regeneration due to overgrazing has also been reported in North Caucasus (Ukraine). The threat of soil erosion is huge as a result of the overexploitation of forests, fire and intense grazing (Kyriazopoulos et al. 2014).

In some areas of the Carpathians (Czech Republic) the treeline ecotone was subjected to several disturbances, particularly originating from the construction or enlargement of ski resorts, recreation facilities and infrastructure (Cudlín et al. 2013). On the other hand, large tracts of the treeline ecotone are regenerating well via secondary succession due to a reduction in sheep and cattle grazing. (cf. Cudlín et al. 2017). Large-scale windfalls and bark beetle outbreaks in forests below the treeline represent constant pressure on treeline ecosystems resulting in a decrease in the aesthetic qualities of the cultural landscapes and possibly distracting tourists and hikers. These areas are at risk of fire due to forest operations such as road construction and burning wood residuals from salvage logging.

In alpine space, conflicts between stakeholders about ES are common (von der Dunk et al. 2011). In the treelines of the Central Alps (Switzerland) there has been a strong impact from grazing by sheep and cattle, and to some extent, goats (Bebi 1999), followed by a treeline advance as a result of warmer climate and abandonment of cottage farming. In the south-eastern Alps, livestock grazing was historically high at the beginning of the 19th century but decreased after World War II, while pressures from large wild ungulates (mostly red deer Cervus elaphus) remained noticeable in most of the central European mountain forests (e.g. Ficko et al. 2016). One of the most important ES provided by the treeline forests in the Alps is avalanche protection (Bebi et al. 2009), often combined with erosion control (Brang et al. 2006, Huber et al. 2013).

In the northern Scandes on the subarctic mountain plateau Finnmarksvidda and adjoining areas in Finnish Lapland (Kevo), birch forest covers a $300 \mathrm{~km}$ wide zone north of and above the conifer treeline. In contrast to most treeline areas in Europe, these birch forests have been partly overgrazed by domestic reindeer over the last 50 yr (Tømmervik et al. 2005, Cudlín et al. 2017). Since Cladonia lichen is the preferred winter food for reindeer, this overgrazing has dramatically reduced the lichen cover throughout northern Fennoscandia (Helle 2001, Lempa et al. 2005). Because of the warming climate, birch forests are increasingly subjected to attacks by various moth species, particularly Epirrita autumnata (Neuvonen et al. 2005, Skre et al. 2017, this Special), because more insect eggs can survive in milder winters (Tenow et al. 2005).

\subsection{Impacts}

Climate warming has led to increased occurrences of tree diseases (root rot diseases) and insect outbreaks (e.g. moths, bark beetles), which are considered particularly problematic for the northern and central European regions. Several projections have indicated that climate warming is likely to affect the frequency, geographical extent and intensity of insect population outbreaks, with potentially severe consequences for the affected ecosystems (Neuvonen et al. 1999, Ayres \& Lombardero 2000, Volney \& Fleming 2000, Logan et al. 2003, Battisti et al. 2006). However, some disturbances (e.g. insect outbreaks, forest fires on cold soils) may also be beneficial because they could increase recycling of nutrients and production in the long-term.

Increasing risk of wildfires was interpreted mainly as a consequence of summer drought, which was considered particularly critical for the treeline ecosystems during drought years in southern European regions (Hoff 2013) and in central Europe. Such fires strongly impact tourism in the affected areas.

An upward shift of the treeline ecotone and consequently a potential increase in forested area were associated with both warmer climate and abandonment of traditional agricultural and pastoral activities 
in mountainous areas. The majority of the respondents interpreted the upward shift of the ecotone positively, while in a few study cases (e.g. Norway, Spain and Greece) an increase in forest cover was recognized as negative as it would result in a decrease in grassland area, loss of biodiversity and possibly negative influences on tourism.

Loss of biodiversity was interpreted as a negative impact in the treeline ecosystems as a result of intense human activities such as overgrazing and massive tourism. Moreover, climate change might also have negative impacts on biodiversity, as it affects ecosystems and the ability of species to adapt (Gitay et al. 2002).

Among the impacts of climate and land-use changes, wind ( $23 \%$ of the cases), wildfires (16\%) and grazing $(14 \%)$ were mentioned as significant (Fig. 1a-c). Avalanches, root rot diseases and bark beetle outbreaks were considered important in $11 \%$ of case studies. Moth outbreaks were identified as a major disturbance, especially in northern Fennoscandinavia and southern Norway. In Iceland, volcanic activity was identified as causing changes to vegetation assemblages. In all cases, except for the Carpathian Mountains, the impacts of natural disturbances were identified as a negative. Direct human activity by logging was nearly absent in most of the study regions $(84 \%)$ but was recognized in the Caucasus Mountains ( $4 \%$ ).

Pressures in treeline areas may also be induced by stakeholders and ES users. While using the ES, stakeholders pose threats to ecosystems and could potentially change their state (Fig. 2). The strongest beneficiaries of ESs are scientists, who were considered to be the least threatening stakeholders. Much of the benefit also goes to protected area officials, tourism, state parks, hikers and recreationists. Several stakeholders were considered as net beneficiaries, meaning that the benefits they receive from treeline ecosystems are higher relative to the threats. Stakeholders posing relatively high threats were snowmobile users, ski resorts and windmill companies. However, the negative impact of most of the stakeholders was rather low, and the vast majority of stakeholders in the treeline area operate in a sustainable way (Sarkki et al. 2016a).

\subsection{Responses}

Linkages between human responses to the outlined drivers, pressures, and their impacts on the current state of treeline ecosystems and their services
(Table 2) are based on the practices used in the same regions as outlined in Section 3.3.

Mitigation measures were rarely practiced. Among the mitigation measures, adaptations of silvicultural practices as well as re-zoning and re-assessment of the Natura 2000 sites were mentioned. These measures mostly targeted specific objects, and were operating at the local level, such as prescribed fires near National Parks in Spain. The locally or regionally focused actions were not really mitigation measures based on a precautionary principle, but rather were risk-reduction activities taking place after the occurrence of a large windfall event or bark beetle outbreak (e.g. Slovakia, Slovenia, Spain). Moreover, the effectiveness of mitigation measures was considered to be very limited. Most of the mitigation measures resulted from international or national commitments on nature protection or national legislation on reserves and national park territories. Current mitigation measures are focused on improvement and maintenance of the regulating and supporting ESs, but without a systematic approach. No specific mitigation measures at any level were reported from Russia, Norway, Greece and the Kola Peninsula.

Adaptation practices were extremely rare and of limited effectiveness, and they took place mainly at the local level with no evident long-term impact. The general problem of adaptation was that the adaptation measures tried to alleviate the maintenance of all ESs, which is in contradiction to ecosystem functioning. The trade-offs between different ESs may not always be resolved at the same place and same time, which should be accounted for in the projections of future ES portfolios (Sarkki et al. 2016a). No adaptation practices at any level were reported from Russia, Norway, Slovenia, Greece and the Kola Peninsula.

Restoration was also seldom practiced. Soil erosion was recognized as the main problem that required restoration. However, information on the successfulness of the restoration was missing. This is partly due to the limited data about the changes near the treeline ecotone. GIS and remote sensing methods will be helpful to address this issue. Future monitoring of ecosystem changes will answer the question of whether restoration actions are feasible in a highly dynamic social-ecological system such as the treeline.

Governance and political instruments specifically designed for treeline ecosystem restoration or adaptation to changes were not common either. Detailed case study descriptions on best management practices highlighted various methods for land-use planning (Sarkki et al. 2015, 2017b). Many of the 
Table 2. Adaptive measures applied in treeline areas for maintaining ecosystem services (ES). LSU: livestock unit

\begin{tabular}{|c|c|c|c|}
\hline Pressures & State & Impact & Responses \\
\hline $\begin{array}{l}\text { Local climate } \\
\text { fluctuations }\end{array}$ & $\begin{array}{l}\text { Reduced number of } \\
\text { days with snow cover }\end{array}$ & $\begin{array}{l}\text { Fewer positive impacts } \\
\text { (benefits) for skiing } \\
\text { resorts due to shorter } \\
\text { ski season }\end{array}$ & Use of artificial snow \\
\hline $\begin{array}{l}\text { Large predator } \\
\text { conservation policies }\end{array}$ & $\begin{array}{l}\text { Increased number of } \\
\text { predators in the treeline } \\
\text { areas }\end{array}$ & $\begin{array}{l}\text { Predation on herds has } \\
\text { negative impacts on } \\
\text { pastoralism }\end{array}$ & $\begin{array}{l}\text { Intensive herding practices (e.g. shepherd } \\
\text { dogs, electric fences), state compensation } \\
\text { to cover losses }\end{array}$ \\
\hline Building ski slopes & Erosion & $\begin{array}{l}\text { Negative impact on } \\
\text { aesthetic value }\end{array}$ & Land-use zoning, priority areas \\
\hline $\begin{array}{l}\text { Use of motorized } \\
\text { vehicles }\end{array}$ & $\begin{array}{l}\text { Trampling effects; } \\
\text { experience of nature } \\
\text { disturbed }\end{array}$ & $\begin{array}{l}\text { Ecotourists dislike this, } \\
\text { attractiveness of the area } \\
\text { decreases }\end{array}$ & $\begin{array}{l}\text { Rules on how protected areas can be } \\
\text { accessed }\end{array}$ \\
\hline Land abandonment & $\begin{array}{l}\text { Encroachment, } \\
\text { nitrification in the areas } \\
\text { with excess LSUs }\end{array}$ & $\begin{array}{l}\text { Decreasing proportion } \\
\text { of pastures }\end{array}$ & $\begin{array}{l}\text { Agri-environmental schemes, e.g. } \\
\text { management of low-intensity pasture } \\
\text { systems, min.-max. LSU load control, } \\
\text { Rumex alpinus control in nitrate-rich } \\
\text { environments }\end{array}$ \\
\hline \multirow[t]{2}{*}{ Warming climate } & Insect attacks & $\begin{array}{l}\text { Negative impact on } \\
\text { economic and aesthetic } \\
\text { value, higher } \mathrm{CO}_{2} \\
\text { emissions }\end{array}$ & $\begin{array}{l}\text { Adapted silviculture, climate-smart } \\
\text { forestry }\end{array}$ \\
\hline & & $\begin{array}{l}\text { More rapid succession } \\
\text { and faster recycling of } \\
\text { nutrients (positive impact) }\end{array}$ & \\
\hline Industrial forestry & $\begin{array}{l}\text { Treeline shift } \\
\text { downwards }\end{array}$ & $\begin{array}{l}\text { Negative impact on } \\
\text { aesthetic value; impacts } \\
\text { on pastures }\end{array}$ & $\begin{array}{l}\text { Collaborative land-use planning, } \\
\text { promoting the principles of continuous- } \\
\text { cover forestry }\end{array}$ \\
\hline Less precipitation & Summer droughts & $\begin{array}{l}\text { Increased risk of wildfires; } \\
\text { deteriorating pastures and } \\
\text { deteriorating aesthetic value }\end{array}$ & $\begin{array}{l}\text { Hazardous fuels reduction programs, } \\
\text { vulnerability zoning, simulation models } \\
\text { for wildfire risk assessment }\end{array}$ \\
\hline
\end{tabular}

European treeline areas include protected areas. The management planning in these areas is not sufficiently linked to other land-use planning and often suffers from inadequate participation of local actors and government sectors, e.g. in municipal zoning to control infrastructure building, forest planning, environmental impact assessment processes linked to industrial developments.

\section{CONCLUSIONS}

Based on 45 case studies, we have come to several conclusions about the social and ecological sustainability of European treeline areas. Firstly, climate change and land-use change represent the 2 most significant drivers in treeline areas. However, unlike most previous analyses of treeline dynamics, our synthesis suggests that land-use change is a more immediate threat to the social and ecological sustainability of European treeline areas than climate change. This calls for paying more attention to human and localspecific pressures instead of fine-tuning climate change scenarios. Secondly, examples from different parts of Europe have evidenced that maintaining traditional pastoral practices in treeline areas in combination with sustainable tourism could enhance social and ecological sustainability. Thirdly, in analyzing the social-ecological systems with the DPSIR framework, it is crucial to be aware that the state dimension should be regarded as a state of a social-ecological system, not as a state of an ecological system (cf. Sarkki et al. 2017a). This distinction is not entirely academic, and has implications for the sustainability of ESs, which are not solely the benefits that ecosystems provide to human well-being, but benefits co-evolved through centuries of human-environment coexistence. Consequently, society must adapt to the changing nature of treeline ESs and look also for new opportunities arising from environmental change, rather than trying to sustain the current level of ESs indefinitely. Finally, policy and governance systems 
that have so far been incoherent and not specifically focused on treeline areas should be proactive without being bureaucratic (Heikkinen et al. 2010). More emphasis should be given to local stakeholder participation in decision making, enhancing local acceptability of decisions. The results from this study indicate that without proactive response to changes, some ESs may be lost in the following decades, changing historical landscapes, reducing financial and other benefits, decreasing biodiversity and consequently, reducing the opportunity to maintain ESs in the future.

Acknowledgements. This study is based upon work from the COST Action ES1203 'Enhancing the resilience capacity of SENSitive mountain FORest ecosystems under environmental change' (SENSFOR), and supported by European Cooperation in Science and Technology (COST) (www.cost.eu). Svetla Bratanova-Doncheva, Pavel Cudlín, Concepcion Alados, Karsten Grunewald, Johann Thorsson and Annika Hofgaard are particularly acknowledged for valuable input to the study.

\section{LITERATURE CITED}

Alados CL, Errea P, Gartzia M, Saiz H, Escós J (2014) Positive and negative feedbacks and free-scale pattern distribution in rural-population dynamics. PLOS ONE 9: e114561

Ameztegui A, Coll L, Brotons L, Ninot JM (2016) Land-use legacies rather than climate change are driving the recent upward shift of the mountain treeline in the Pyrenees. Glob Ecol Biogeogr 25:263-273

Ayres MP, Lombardero MJ (2000) Assessing the consequences of global change for forest disturbance from herbivores and pathogens. Sci Total Environ 262:263-286

Bakaloudis DE (2016) Livestock grazing, openings and raptors conservation in the Dadia-Lefkimi-Soufli forest national park. Options Mediterraneennes Ser A 114: 437-440

Battisti A, Stastny M, Buffo E, Larsson S (2006) A rapid altitudinal range expansion in the pine processionary moth produced by the 2003 climatic anomaly. Glob Change Biol 12:662-671

Bebi P (1999) Erfassung von Strukturen im Gebirgswald als Beurteilungsgrundlage ausgewählter Waldwirkungen. PhD thesis, ETHZ, Zürich

Kebi P, Kulakowski D, Rixen C (2009) Snow avalanche disturbances in forest ecosystems - state of research and implications for management. For Ecol Manage 257: 1883-1892

Boyd J, Banzhaf S (2007) What are ecosystem services? The need for standardized environmental accounting units. Ecol Econ 63:616-626

Brang P, Schönenberger W, Frehner M, Schwitter R, Thormann JJ, Wasser B (2006) Management of protection forests in the European Alps: an overview. For Snow Landsc Res 80:23-44

Broll G, Keplin B (eds) (2005) Mountain ecosystems: studies in treeline ecology. Springer, Berlin Heidelberg

Bryn A, Daugstad K (2001) Summer farming in the sub- alpine birch forest. In: Wielgolaski FE (ed) Nordic mountain birch ecosystems. UNESCO, Paris, p 307-315

* Camarero JJ, Garcia-Ruiz JM, Sangüesa-Barreda G, Galvàn JD and others (2015) Recent and intense dynamics in a formerly static Pyrenean treeline. Arct Antarct Alp Res 47:773-783

* Cooper P (2013) Socio-ecological accounting: DPSWR, a modified DPSIR framework, and its application to marine ecosystems. Ecol Econ 94:106-115

Cudlín P, Seják J, Pokorný J, Albrechtová J, Bastian O, Marek M (2013) Forest ecosystem services under climate change and air pollution. In: Matyssek R, Clarke $\mathrm{N}$, Cudlín P, Mikkelsen TN, Tuovinen JP, Wiesner G, Paoletti E (eds) Climate change, air pollution and global challenges: understanding and perspectives from forest research. Developments in Environmental Science, Vol 13. Elsevier, Oxford, p 521-546

Cudlín P, Klopčič M, Tognetti R, Malis F and others (2017) Drivers of treeline shift in different European mountains. Clim Res in press 73:135-150

Dakov MI, Iliev DA, Donov V, Dimitrov S (1980) Increase of upper forest line. Zemizdat, Sofia (in Bulgarian)

* Danell LS, Niemelä P, Varvikko T, Vuorisalo T (1991) Moose browsing on Scots pine along a gradient of plant productivity. Ecology 72:1624-1633

* De Wit HA, Bryn A, Hofgaard A, Karstensen J, Kvalevåg M, Peters G (2014) Climate warming feedback from mountain birch forest expansion: reduced albedo dominates carbon uptake. Glob Change Biol 20:2344-2355

* Debussche M, Lepart J, Dervieux A (1999) Mediterranean landscape changes: evidence from old postcards. Glob Ecol Biogeogr 8:3-15

EEA (European Environmental Agency) (2016) Environmental terminology and discovery service (ETDS). http:// glossary.eea.europa.eu/terminology/concept_html?term =dpsir

Ficko A, Roessiger J, Bončina A (2016) Can the use of continuous cover forestry alone maintain silver fir (Abies alba Mill.) in central European mountain forests? Forestry 89:412-421

* Gartzia M, Alados CL, Pérez-Cabello F (2014) Assessment of the effects of biophysical and anthropogenic factors on woody plant encroachment in dense and sparse mountain grasslands based on remote sensing data. Prog Phys Geogr 38:201-217

*Gehrig-Fasel J, Guisan A, Zimmermann NE (2007) Tree line shifts in the Swiss Alps: climate change or land abandonment? J Veg Sci 18:571-582

Gitay H, Suarez A, Watson R, Dokken D (eds) (2002) Climate change and biodiversity. IPPC Technical Paper V. Intergovernmental Panel on Climate Change, Geneva

Grabherr G (2009) Biodiversity in the high ranges of the Alps: ethnobotanical and climate change perspectives. Glob Environ Change 19:167-172

* Grace J, Berninger F, Nagy L (2002) Impacts of climate change on the tree line. Ann Bot 90:537-544

Grunewald K, Bastian O (eds) (2015) Ecosystem servicesconcept, methods and case studies. Springer-Verlag, Heidelberg

Grunewald K, Scheithauer J (2011) Landscape development and climate change in Southwest Bulgaria (Pirin Mountains). Springer, Heidelberg

*Hastik R, Basso S, Geitner C, Haida C and others (2015) Renewable energies and ecosystem service impacts. Renew Sustain Energy Rev 48:608-623 
Heikkinen HI, Sarkki S, Jokinen M, Fornander DE (2010) Global area conservation ideals versus the local realities of reindeer herding in northernmost Finland. Int J Bus Glob 4:110-130

Helle T (2001) Mountain birch forests and reindeer husbandry. In Wielglaski FE (ed) Nordic mountain birch ecosystems. UNESCO, Paris, p 279-291

Hester AJ, Miller DR, Towers W (1996) Landscape scale vegetation change in the Cairngoms, Scotland 1946-1988: implication for land management. Biol Conserv 77:41-52

Hester AJ, Millard P, Baillie GJ, Wendler R (2004) How does timing of browsing affect above- and belowground growth of Betula pendula, Pinus sylvestris and Sorbus aucuparia? Oikos 105:536-550

Hoff H (2013) Vulnerability of ecosystem services in the Mediterranean region to climate changes in combination with other pressures. In: Navarra A, Tubiana L (eds) Regional assessment of climate change in the Mediterranean. Advances in Global Change Research, Vol 51. Springer, Dordrecht, p 9-29

Hofgaard A, Tømmervik H, Rees G, Hanssen F (2013) Latitudinal forest advance in northermost Norway since the early $20^{\text {th }}$ century. J Biogeogr 40:938-949

Holtmeier FK (2009) Mountain timberlines: ecology, patchiness and dynamics. In: Beniston $M$ (ed) Advances in Global Change Research, Vol 36. Springer, Dordrecht, p 5-167

Huber R, Rigling A, Bebi P, Brand FS and others (2013) Sustainable land use in mountain regions under global change: synthesis across scales and disciplines. Ecol Soc 18:36

Körner C (2012) Alpine treelines: functional ecology of the high elevation tree limits. Springer, Basel

Kullman L (2004) The changing face of the alpine world. Global Change Newsl 57:12-14

Kullman L, Öberg L (2009) Post-Little Ice Age tree line rise and climate warming in the Swedish Scandes: a landscape ecological perspective. J Ecol 97:415-429

Kupfer JA, Cairns DM (1996) The suitability of montane ecotones as indicators of global climatic change. Prog Phys Geogr 20:253-272

Kyriazopoulos AP, Abraham E, Hofgaard A, Sarkki S (2014) DPSIR for treeline ecosystem and their services. Progress Report COST Action ES1203, COST/EU, Brussels

Lempa K, Neuvonen S, Tømmervik H (2005) Effects of reindeer grazing on pastures - a necessary basis for sustainable reindeer herding. In: Wielgolaski FE (ed) Plant ecology, herbivory and human impact in Nordic mountain birch forests. Ecological Studies, Vol 180. Springer, Berlin Heidelberg p 157-164

Logan JA, Regniere J, Powell JA (2003) Assessing the impacts of global warming on forest pest dynamics. Front Ecol Environ 1:130-137

Luck GW, Harrington R, Harrington PA (2009) Quantifying the contribution of organisms to the provision of ecosystem services. Bioscience 59:223-235

Neuvonen S, Niemelä P, Virtanen T (1999) Climatic change and insect outbreaks in boreal forests: the role of winter temperatures. Ecol Bull 47:63-67

Neuvonen S, Bylund H, Tømmervik H (2005) Forest defoliation risks in birch forest by insects under different climate and land use scenarios in northern Europe. In: Wielgolaski FE (ed) Plant ecology, herbivory and human impact in Nordic mountain birch forests. Ecological Studies, Vol 180. Springer, Berlin Heidelberg, p 125-138
Oksanen L, Moen J, Helle T (1995) Timberline patterns in northernmost Fennoscandia: relative importance of climate and grazing. Acta Bot Fenn 153:93-105

* Palombo C, Chirici G, Marchetti M, Tognetti R (2013) Is land abandonment affecting forest dynamics at high elevation in Mediterranean mountains more than climate change? Plant Biosyst 147:1-11

* Papanastasis VP (2009) Restoration of degraded grazing lands through grazing management: Can it work? Restor Ecol 17:441-445

Paulsen J, Körner C (2014) A climate-based model to predict potential treeline position around the globe. Alp Bot 124: $1-12$

Potthoff K (2009) Grazing history affects the tree-line ecotone: a case study from Hardanger, western Norway. Fennia 187:81-98

Rapport D, Friend A (1979) Toward a comprehensive framework for environmental statistics: a stress-response approach. Statistics Canada, Ottawa

Sarkki S, Grunewald K, Alados CL, Nijnik M and others (2013) Questionnaire-based investigation of stakeholder needs as linked to ecosystem services, governance and science in European treeline areas, Progress Report, COST Action ES1203, COST/EU, Brussels

Sarkki S, Grunewald K, Nijnik M, Zahvoyska L and others (2015) Problems and proposals for good environmental management: empirical assessment of European treeline areas. Progress Report, COST Action ES1203, COST/EU, Brussels

Sarkki S, Ficko A, Grunewald K, Nijnik M (2016a) Benefits from and threats to European treeline ecosystem services: an exploratory study of stakeholders and governance. Reg Environ Change 16:2019-2032

Sarkki S, Ficko A, Grunewald K, Kyriazopoulos AP, Nijnik M (2016b) How pragmatism in environmental science and policy can undermine sustainability transformations: the case of marginalized mountain areas under climate and land-use change. Sustain Sci 4, doi:10.1007/s11625016-0411-3

Sarkki S, Ficko A, Wielgolaski FE, Abraham EM and others (2017a) Assessing the resilient provision of ecosystem services by social-ecological systems: introduction and theory. Clim Res 73:7-15

Sarkki S, Jokinen M, Nijnik M, Zahvoyska L and others (2017b) Social equity in governance of ecosystem services: synthesis from European treeline areas. Clim Res 73:31-44

Sarvašová Z, Cienciala E, Beranová J, Vančo M, Ficko A, Pardos M (2014) Analysis of governance systems applied in multifunctional forest management in selected European mountain regions. For J 60:159-167

Skre O, Baxter R, Crawford RMM, Callaghan TV, Fedorkov A (2002) How will the tundra-taiga interface respond to climate change? Ambio (Spec Rep) 12:37-46

Skre O, Wertz B, Wielgolaski FE, Szydlowska P, Karlsen SR (2017) Bioclimatic effects on different mountain birch populations in Fennoscandia. Clim Res 73:111-124

Smith WK, Germino MJ, Hancock TE, Johnson DM (2009) The altitude of alpine treeline: a bellwether of climate change effects. Bot Rev 75:163-190

Tenow O, Bylund H, Nilsen AC, Karlsson PS (2005) Longterm influences of herbivores on northern birch forests. In: Wielgolaski, FE (ed) Plant ecology, herbivory and human impact in Nordic mountain birch forests. Ecological Studies, Vol 180. Springer, Berlin, p 165-182 
Theurillat JP, Guisan A (2001) Potential impact of climate change on vegetation in the European Alps: a review. Clim Change 50:77-109

Tolvanen A, Forbes B, Wall S, Norokorpi Y (2005) Recreation at tree-line and interactions with other land-use activities. In Wielgolaski FE (ed) Plant ecology, herbivory and human impact in Nordic mountain birch forests. Ecological Studies, Vol 180. Springer, Berlin, p 203-217

Tømmervik H, Wielgolaski FE, Neuvonen S, Solberg B, Høgda KA (2005) Biomass and production at a landscape level in the northern mountain birch forests. In: Wielgolaski FE (ed) Plant ecology, herbivory and human impact in Nordic mountain birch forests. Ecological Studies, Vol 180. Springer, Berlin, p 53-70
Van Bogaert R, Haneca K, Hoogesteger J, Jonasson C, De Dapper M, Callaghan T (2011) A century of treeline changes in subarctic Sweden shows local and regional variability and only a minor influence of $20^{\text {th }}$ century climate warming. J Biogeogr 38:907-921

Volney WJA, Fleming RA (2000) Climate change and impacts of boreal forest insects. Agric Ecosyst Environ 82: 283-294

* von der Dunk A, Gret-Regamey A, Dalang T, Hersperger AM (2011) Defining a typology of peri-urban land-use conflicts - a case study from Switzerland. Landsc Urban Plan 101:149-156

Xirouchakis S (2004) Causes of raptor mortality in Crete. In: Meyburg BU, Chancellor R (eds) Raptors worldwide. WWGBP/MME (Birdlife Hungary), Berlin, p 849-860
Fig. A1. Application of the driverspressures-state-impacts-responses (DPSIR) framework for treeline ecotones in Europe (Kyriazopoulos et al. 2014)

\section{Appendix}

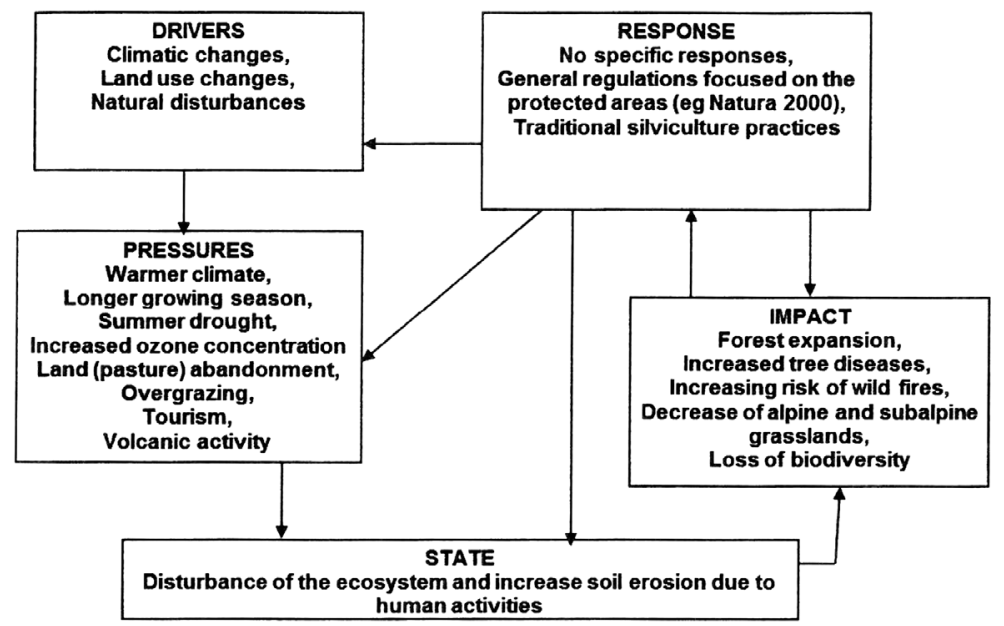

Table A1. Example of the description protocol for drivers, pressures, state, impacts and responses in the second survey (Kyriazopoulos et al. 2014). Colour shading - grey: location, climate and species; green: land use types; blue: climate change types; red: DPSIR factors

\begin{tabular}{|ll|}
\hline Location & Western Carpathian Mts \\
& N $48^{\circ} 48^{\prime}$ to $49^{\circ} 35^{\prime}$, E $19^{\circ} 18^{\prime}$ to $21^{\circ} 00^{\prime}$ \\
& Elevation $>1200$ to $1850 \mathrm{~m}$ \\
Climate & Mountainous \\
Dominant tree species & Pinus mugo, Pinus cembra, Picea abies, Fagus sylvatica \\
Wild herbivores & Cervus elaphus, Rupicapra rupicapra, Ursus arctos \\
Land use changes & Pasture abandonment \\
Grazing / livestock & Decreased / sheep and cattle \\
Logging pressure & No \\
Climatic changes & Climate warming \\
Temperature trend & Increase \\
Precipitation trend & Slightly increase \\
Driving forces & Climatic changes, land-use changes \\
Pressure & Climate warming, decreased grazing \\
State & Treeline is being increasingly disturbed, particularly by construction/enlargement of ski resorts and \\
& other recreation facilities. Regeneration via secondary succession due to abandonment of grazing \\
Impact & Longer growing season, bark beetle outbreaks \\
Responses & Creation of nature protection zones, or specific parts of Rural Development Programme dedicated \\
& to treeline ecosystems. Silviculture measures \\
\hline
\end{tabular}

